\title{
OXYGEN CONSUMPTION AND ENERGY EXPENDITURE DURING AND AFTER STREET GAMES, ACTIVE VIDEO GAMES AND TV
}

\author{
CONSUMO DE OXIGÊNIO E GASTO ENERGÉTICO DURANTE EDEPOIS DE BRINCADEIRAS DERUA, VÍDEO \\ GAMESATIVOSETV
}

CONSUMO DE OXÍGENO Y GASTO ENERGÉTICO DURANTE Y DESPUÉS DE JUEGOS DE CALLE, VÍDEO GAMEYTV

\begin{abstract}
Suliane Beatriz Rauber
(Physical Education Professional) $)^{1,2}$

Pierre Soares Brandão

(Physical Education Professional

and Physiotherapist $)^{3}$

José Fernando Vila Nova de Moraes (Physical Education Professional) $^{4}$

Bibiano Madrid

(Physical Education Professional) $^{3}$

Daniel Fernandes Barbosa

(Psychologist) $^{5}$

Herbert Gustavo Simões (Physical Education Professional) $^{2}$

John Eugene Lewis (Exercise

Physiologist) ${ }^{6}$

Carmen Sílvia Grubert Campbell

(Physical Education Professional) $^{3}$
\end{abstract}

\begin{abstract}
1. Centro Universitário do Distrito Federal (UDF), Brasília, DF, Brazil.

2. Universidade Católica de Brasília

(UCB), Taguatinga, DF, Brazil.

3. Centro Universitário Luterano de Palmas (CEULP), Palmas, TO, Brazil. 4. Universidade Federal do Vale do São Francisco (UNIVASF), Petrolina, PE, Brazil.

5. Centro Universitário do Grupo Educacional Ceuma (UNIEURO), Brasília, DF, Brazil

6. University of Miami, Coral Gables, FL, USA.
\end{abstract}

\section{Correspondence:}

Suliane B. Rauber, Laboratory Study of Physical Activity and Health, Universidade Católica de Brasília, QS 07, Lote 01, Águas Claras, 71966-700, Brasilia, Brazil. professora.suliane@gmail.com

\begin{abstract}
Introduction: Physical activity has become less frequent since the 1980s, even among more active children. Objective: To analyze excess post-exercise oxygen consumption (EPOC) and total energy expenditure (TEE) in children during and after three different activities. Methods: Sixteen healthy children (9.6 \pm 0.1 yrs.) randomly underwent the following procedures lasting 30 minutes on different days: (a) traditional games (PLAY), (b) active video game (Dance Dance Revolution; DDR), and (c) watching television (TV). Oxygen consumption $\left(\mathrm{VO}_{2}\right)$ was measured at rest, at the $10^{\text {th }}, 20^{\text {th }}$, and $30^{\text {th }}$ minute of intervention, and for 40 minutes post-intervention. TEE was also measured. Results: At the end of intervention, $\mathrm{VO}_{2}$ had increased by $330 \%$ and $166 \%$ for $\mathrm{PLAY}$ and DDR, respectively, compared to the rest. EPOC in PLAY was seen to occur at the $10^{\text {th }}, 20^{\text {th }}$, and $30^{\text {th }}$ post-interventional minutes from $7.00 \pm 1.02$ (at rest) to $10.83 \pm 0.94,10.03 \pm 0.58$, and $9.80 \pm 0.77 \mathrm{~mL}^{\mathrm{kg}} \mathrm{kg}^{-1} \cdot \mathrm{min}^{-1}$, respectively. However, EPOC in DDR occurred at only the $10^{\text {th }}$ post-

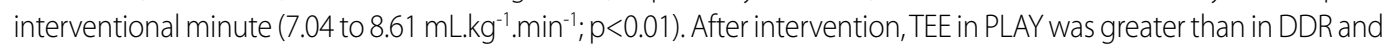
TV (112.08 \pm 19.45 vs $56.98 \pm 6.34$ vs $36.39 \pm 4.5 \mathrm{kcal} ; p<0.01)$, respectively. Conclusions: PLAY induced children to reach a greater $\mathrm{VO}_{2}$ during activity and greater EPOC and TEE compared to DDR and TV. Level of evidenceA1b; Crossover study.
\end{abstract}

Keywords: Children; Oxygen consumption; Heart rate.

\section{RESUMO}

Introdução: A prática de atividade fisica tornou-se menos frequente a partir dos anos 80 , mesmo entre crianças mais ativas. Objetivo: Analisaro consumo excessivo de oxigênio pós-exercício (EPOC) eo gasto energético total (TEE) em crianças durante e após três atividades distintas. Métodos: Dezesseis crianças saudáveis $(9,6 \pm 0,1$ anos) foram submetidas aleatoriamente aos seguintes procedimentos com duração de 30 minutos em dias diferentes: (a) brincadeiras tradicionais (PLAY), (b) videogame ativo (Dance Dance Revolution, DDR) e (c) assistir à televisão (TV). O consumo de oxigênio $\left(V \mathrm{~V}_{2}\right)$ foi medido em repouso, no 10',20 e $30^{\circ}$ minuto de intervenção e 40 minutos depois da intervenção. O TEE também foi calculado. Resultados: No final da intervenção, o VO 2 aumentou 330\% e 166\% para PLAY e DDR, respectivamente, em comparação com o repouso. Observou-se que o EPOC no PLAY ocorreu aos 10, 20 e 30 minutos depois da intervenção, de 7,00 $\pm 1,02$ (em

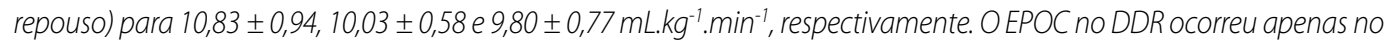
$10^{\circ}$ minuto pós-intervenção $\left(7,04\right.$ a $8,61 \mathrm{~mL}^{\mathrm{kg}} \mathrm{kg}^{-1}$. $\left.\mathrm{min}^{-1}, p<0,01\right)$. Após a intervenção, O TEE no PLAY foi maior que em DDR eTV (112,08 $\pm 19,45$ vs. $56,98 \pm 6,34$ vs. $36,39 \pm 4,5 \mathrm{kcal}, p<0,01)$, respectivamente. Conclusões: OPLAY induziu as crianças a maior $\mathrm{VO}_{2}$ durante a atividade e maior EPOC e TEE com relação a DDR e TV. Nível de evidência A1b; Estudo cruzado.

Descritores: Crianças; Consumo de oxigênio; Frequência cardíaca.

\section{RESUMEN}

Introducción: La actividad física se ha vuelto menos frecuente desde la década de 1980, incluso entre los niños más activos. Objetivo: Analizar el consumo excesivo de oxígeno post ejercicio (EPOC) y el gasto de energía total (TEE) en niños durante y después del juego activo tradicional y comparar con el video game activo y televisión. Métodos: Dieciséis niños saludables (9,6 $\pm 0,1$ años) fueron sometidos durante 30 minutos, en dias diferentes, a las siguientes sesiones: (a) juegos tradicionales (PLAY), (b) video game activo (DDR) y (c) televisión (TV). El consumo de oxígeno $\left(\mathrm{VO}_{2}\right)$ fue medido en reposo en el 10,20 y $30^{\circ}$ minuto de intervención y durante 40 minutos después de la intervención. El TEE se calculó a partir de datos $\mathrm{VO}_{2}$. Resultados: Durante las sesiones de $\mathrm{VO}_{2}$ aumentó un $330 \%$ y $166 \%$ para $P L A Y$ y DDR, respectivamente, en relación al reposo. Se observó que el EPOC en PLAY se produjo a los 10,20y 30 minutos post intervención 7,00 $\pm 1,02$ (en reposo) a 10,83 $\pm 0,94,10,03 \pm 0,58 \mathrm{y} 9,80 \pm 0,77 \mathrm{~mL} . \mathrm{kg}^{-1} . \mathrm{min}^{-1}$, respectivamente. EI EPOC en DDR se produjo apenas en el $10^{\circ}$ min después de la intervención (7,04 a la 8,61 mL.kg-1. $\left.\mathrm{min}^{-1}, p<0,01\right)$. Después de la intervención, el TEE fue mayor en el DDRy TV $(112,08 \pm$ 19,45 vs 56,98 $\pm 6,34$ vs 36,39 $\pm 4,5$ kcal, $P<0,01$ ), respectivamente. Conclusión: La sesión PLAY llevó a un mayor VO ${ }_{2}$ durante la actividad y mayor EPOC y gasto de energía en relación a la DDRy TV. Nivel de evidencia A1b; Estudio crossover con.

Descriptores: Niños; Consumo de Oxígeno; Frecuencia cardiaca. 


\section{INTRODUCTION}

Physical activity has become less frequent since the 1980s, even among more active children. ${ }^{1}$ Nowadays, many kids around the world spend numerous hours a day watching TV or playing sedentary videogames, contributing to an increased risk of cardiovascular disease.,3

Physical activity is considered essential to children's health. ${ }^{4}$ Therefore, activities involving traditional children's games and active videogames have been suggested to satisfy and improve physical activity levels. ${ }^{5}$ Moreover, recent studies have indicated that active videogames can increase energy expenditure (EE) among schoolchildren ${ }^{6}$ and have been associated with improvement in health-related markers. ${ }^{7}$ Active games elevate $\mathrm{EE}$, have the potential to increase physical activity, and have a positive influence on energy balance. ${ }^{8,9}$

Measurements of oxygen consumption $\left(\mathrm{VO}_{2}\right)$ at rest, during and after physical activity or exercise allow to estimate daily energy expenditure. ${ }^{10}$ Excess post-exercise oxygen consumption (EPOC) is a physiological parameter used to analyze body metabolism and energy expenditure after physical activity. ${ }^{11} \mathrm{~A}$ higher EPOC contributes to a higher EE beyond the promoted during the activity, which helps to control body weight. ${ }^{12}$ In adult studies, EPOC has been observed for as long as 30 minutes $^{13}$ to 12 hours. ${ }^{14}$

Energy imbalance, even with just the consumption of a very few kcal higher than actual expenditure (i.e., $25 \mathrm{kcal} /$ day), may lead to obesity over time. ${ }^{15}$ Christiansen et al. ${ }^{12}$ developed a mathematical model to evaluate changes in body mass and values of energy intake and $\mathrm{EE}$, controlling for physical activity. The application of the model showed that an increase in body mass of $1 \mathrm{~kg} /$ year corresponded to an imbalance of $16.9 \mathrm{kcal} /$ day for men, and $82 \%$ of this amount was stored in the body, while $18 \%$ was used for energy conversion.

EPOC means that extra energy has been used beyond the utilized during physical activity. The extra EE after exercise is important for individuals who want to reduce body weight. ${ }^{2}$ Exercise mode, duration, and intensity may impact the duration and magnitude of EPOC in adults, ${ }^{17}$ but little is known about the effect in children. Therefore, the aim of the present study was to compare $\mathrm{VO}_{2}$ and EE during and after interventions such as traditional play, active videogames, and watching television. We hypothesized that active play would elicit the highest $\mathrm{VO}_{2}$ and $\mathrm{EPOC}$, and thus $\mathrm{EE}$, during and after the activity.

\section{MATERIAL AND METHODS}

A random sample of sixteen schoolchildren aged 9-10 years (8 boys and 8 girls) participated in the study. The main characteristics of the participants are presented in Table 1. After authorization from the school, the children's parents received an informed consent letter describing all procedures of the study and signed the consent for the children's participation.

The exclusion criteria were: (a) physical impairments that could prevent the participant from performing the activities; (b) existence of any previous cardiometabolic disease (e.g., diabetes or hypertension); and (c) any previous experience with the video game "Dance Dance Revolution"(DDR). The study was approved by the local ethics committee for human research (protocol 147/2009).

\section{Procedures}

All procedures were performed at a multi-sports gym and at the Laboratory of Studies in Physical Education and Health at the Catholic University of Brasília, Brazil. The participants were instructed to come to the laboratory fasted, while maintaining their regular eating habits the day before, to analyze resting $\mathrm{VO}_{2}$ (measured after a 10-minute seated period). After this measurement, the participant received a standard snack prescribed by a nutritionist [orange juice $(200 \mathrm{ml}, 100 \mathrm{kcal}, 28 \mathrm{~g}$ of carbohydrate) and a pack of crackers ( $92 \mathrm{kcal}, 17 \mathrm{~g}$ of carbohydrate, $2.9 \mathrm{~g}$ of protein, and $5 \mathrm{~g}$ of total fat)].

The participants attended four visits on different days, 24 hours apart from each other. The first visit consisted of anthropometric evaluation and familiarization. The following visits, described below, were performed in a randomized order, on different days, between 8 and 11 AM. Each visit lasted 80 minutes and included 10 minutes of rest, 30 minutes of activity, and 40 minutes of recovery.

\section{Familiarization with the Intervention and Anthropometric Evaluation}

The participants received orientations and were familiarized with the procedures and equipment that would be used during the experimental sessions. Each child learned how to play the DDR video game 15 times, during 30 minutes, supervised by a research team member.

Body mass (Electronic Scale Tech 05 ${ }^{\circledR}$, China), height (Portable Stadiometer, Sanny ${ }^{\circledR}$, Brazil), and subscapular and triceps skinfolds (Lange Skinfold Caliper, USA) were evaluated. Body fat was estimated according to Slaughter et al..18

Traditional Children's Games Session (PLAY): In this session, each child was evaluated individually on different days. PLAY was performed with other kids ( $n=7$ ) to motivate the child and make the session as close to real as possible. This activity consisted of three traditional running games usually played by many kids around the world, as follows: 10 minutes of "Tag! You're it!", 10 minutes of "dodge ball", and 10 minutes of "capture the flag". Heart rate (HR) (Polar Electro Oy, Finland) and $\mathrm{VO}_{2}$ (Cortex Metamax 3B - Biophysik, Germany) were measured immediately after each game.

Dance Dance Revolution Session (DDR): Participants played an interactive videogame (DDR - Pump it up for Playstation ${ }^{\circledR}$ ) installed on a laptop computer (LG, S460 14, SP - Brazil). They were not familiar with DDR before participating in the study. The selected songs were from a basic low-level difficulty list.

Watching Television Session (TV): Participants watched two popular cartoons ("Sponge Bob" and "Ben 10") during 30 minutes (15 minutes per cartoon) while seated in a quiet room. The cartoons were also shown on a laptop computer (LG S460 14, SP - Brazil).

Oxygen Uptake and Heart Rate Measurement: Oxygen uptake $\left(\mathrm{VO}_{2}\right)$ was measured through expired gas by using a portable analyzer (Córtex MetaMax 3B - Biophysik, Germany) with a pediatric mask attached to the participant. Figure 1 displays the timing of each measurement. EE was calculated assuming that each litre of $\mathrm{VO}_{2}$ represented an expenditure of $5 \mathrm{kcal}$ or $20.92 \mathrm{~kJ} .^{17} \mathrm{HR}$ was measured using a monitor (Polar Electro Oy, Finland), and HR maximum (HRmax) was estimated with the equation HRmax $=208-(0.7 \times$ age $) .{ }^{18}$

\section{Statistical Procedures}

Data were expressed as mean \pm standard error of mean. To determine the effect of the different sessions (PLAY, DDR, and TV), a one-factor analysis of variance (ANOVA) was performed. EE of each session was compared using one-way ANOVA. Main effects were evaluated with Bonferroni's post hoc comparisons. A post hoc analysis on the effects found was performed to identify the adequacy of the sample. The level of statistical significance used was $p<0.05$. All statistics were performed using SPSS 22.0 (IBM, Inc., Chicago, IL). 

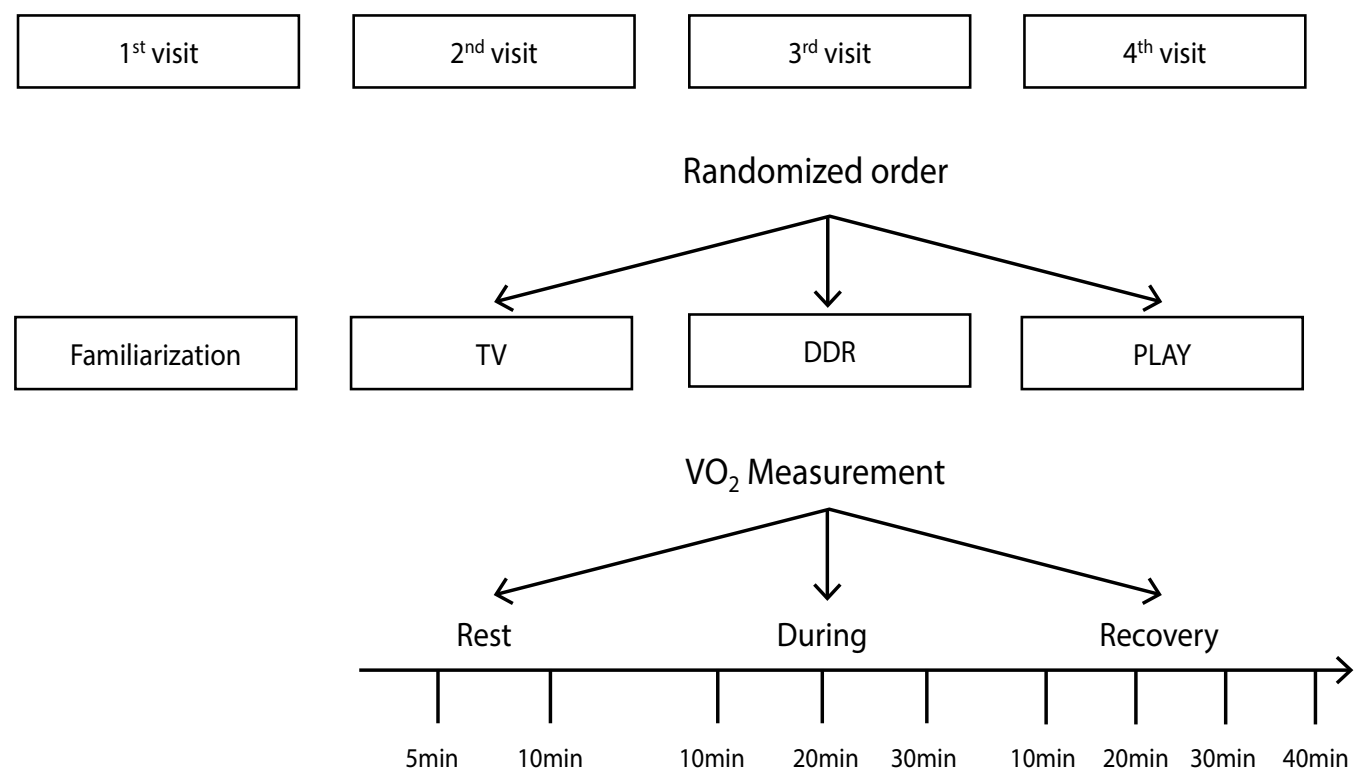

Figure 1. Study Design Including Schedule of $\mathrm{VO}_{2}$ Measurements.

\section{RESULTS}

The coefficient of variation of the main characteristics of the sample showed little dispersion with values from 5.2\% to 21.8\% (Table 1), characterizing the sample as homogeneous. The mean values for body mass, height, body mass index (BMI), and body fat of the participants were close to the $50^{\text {th }}$ percentile for their respective sex and age. ${ }^{19}$ The mean resting values for systolic blood pressure $(101.0 \pm 2.5 \mathrm{mmHg})$ and diastolic blood pressure $(65.9 \pm 1.4 \mathrm{mmHg})$ corresponded to the 50th and 60th percentile, respectively, according to the National High Blood Pressure Education Program (NHBPEP). ${ }^{20}$

Table 2 presents the cardiovascular responses during the activity sessions. The variables at rest were not different between sessions. However, during the sessions, HR, BP, and double product (DP) after DDR and PLAY differed significantly from rest. These variables were significantly higher during PLAY when compared to DDR and TV, and during DDR when compared to TV.

Table 3 presents the $\mathrm{VO}_{2}$ during all sessions. EPOC was observed until the $20^{\text {th }}$ and $30^{\text {th }}$ minute of recovery of DDR and PLAY, respectively.

Table 4 presents the $\mathrm{kcal}$ and $\mathrm{kcal} / \mathrm{min}$ expended at rest, during sessions, during the post-intervention recovery period, and of the whole session.

Table 1. Physical Characteristics of the Participants $(n=16)$.

\begin{tabular}{c|c|c}
\hline Variables & Mean \pm SEM & $\mathbf{C}_{\mathbf{v}}$ (\%) \\
\hline Age (years) & $9.6 \pm 0.1$ & 5.21 \\
\hline Height $(\mathrm{cm})$ & $133.8 \pm 2.3$ & 7.40 \\
\hline Weight $(\mathrm{kg})$ & $32.4 \pm 0.09$ & 12.35 \\
\hline BMl $\left(\mathrm{kg} / \mathrm{m}^{2}\right)$ & $18.4 \pm 0.9$ & 21.84 \\
\hline Body fat $(\%)$ & $17.4 \pm 0.9$ & 21.84 \\
\hline
\end{tabular}

The kcal expended at rest was not different between sessions. EE was higher after PLAY and DDR when compared to TV during the session, recovery, and whole session. EE after PLAY was also significantly higher when compared to DDR at the same moments. EE during TV did not changed when compared to rest. Estimated EE by all expired gases during sessions revealed a higher total caloric expenditure after PLAY when compared to DDR and TV (112.2 $\pm 2.5 \mathrm{kcal}$ vs $56.7 \pm 1.6 \mathrm{kcal}$ vs $36.3 \pm 1.8 \mathrm{kcal} ; \mathrm{p}<0.05)$, respectively.

Figure 2 shows MET values at rest and during the sessions. MET was significantly higher during PLAY and DDR when compared to TV ( 236\% and $\sim 45 \%$ higher, respectively).

RER was not different at rest. However, during sessions, RER was significantly higher during PLAY when compared to DDR and TV and also during DDR when compared to TV (data not shown). During 20 minutes of post-intervention recovery, PLAY presented higher RER when compared to rest. On the other hand, RER increased only during 10 minutes after DDR. RER during PLAY and DDR decreased during the entire post-exercise recovery period.

Table 3. Mean ( \pm SEM) Values of $\mathrm{VO}_{2}$ at Rest and During and After Sessions ( $\left.n=16\right)$.

\begin{tabular}{|c|c|c|c|}
\hline Moment & 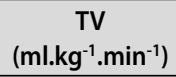 & 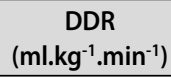 & 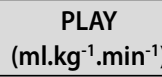 \\
\hline Rest & $7.02 \pm 1.08$ & $7.04 \pm 1.07$ & $7.00 \pm 1.02$ \\
\hline During & $7.5 \pm 1.0$ & $11.7 \pm 1.3^{* \dagger}$ & $23.1 \pm 4.0^{* \#+}$ \\
\hline Rec $10 \mathrm{~min}$ & $7.23 \pm 1.24$ & $8.61 \pm 1.26^{*+}$ & $10.83 \pm 0.94^{* \#+}$ \\
\hline $\operatorname{Rec} 20 \mathrm{~min}$ & $6.93 \pm 1.23$ & $7.96 \pm 1.02^{*}$ & $10.03 \pm 0.58^{* \#}+$ \\
\hline Rec $30 \mathrm{~min}$ & $6.97 \pm 1.50$ & $7.32 \pm 1.06$ & $9.80 \pm 0.77^{* \#+}$ \\
\hline $\operatorname{Rec} 40 \mathrm{~min}$ & $6.93 \pm 1.31$ & $7.07 \pm 0.98$ & $8.03 \pm 1.88$ \\
\hline
\end{tabular}

SEM = Standard Error of the Mean; TV = watching TV; DDR = Dance Dance Revolution (active videogame); PLAY $=$ traditional children's games; ${ }^{*}<<0.01$ when compared to TV at the same moment; $\# p<0.01$ when compared to DDR at the same moment; $+\mathrm{p}<0.01$ when compared to rest at the same session.

Table 2. Mean ( \pm SEM) of Cardiovascular Variables at Rest and During Sessions $(n=16)$.

\begin{tabular}{|c|c|c|c|c|c|c|}
\hline \multirow{2}{*}{ Variables } & \multicolumn{2}{|c|}{ TV } & \multicolumn{2}{|c|}{ DDR } & \multicolumn{2}{|c|}{ PLAY } \\
\hline & Rest & During & Rest & During & Rest & During \\
\hline $\mathrm{HR}(\mathrm{bpm})$ & $82.9 \pm 5.1$ & $84.9 \pm 4.7$ & $85.4 \pm 5.4$ & $109.1 \pm 9.3^{\# *}$ & $82.6 \pm 5.2$ & $144.9 \pm 11.3^{\# *}+$ \\
\hline $\mathrm{SBP}(\mathrm{mmHg})$ & $99.6 \pm 6.9$ & $99.8 \pm 6.2$ & $99.9 \pm 6.0$ & $115.5 \pm 5.2^{\# *}$ & $99.8 \pm 5.8$ & $138.2 \pm 7.3^{\# *} \dagger$ \\
\hline $\mathrm{DBP}(\mathrm{mmHg})$ & $65.6 \pm 5.0$ & $63.8 \pm 5.9$ & $63.0 \pm 5.4$ & $72.6 \pm 5.0^{\# *}$ & $63.4 \pm 4.7$ & $79.1 \pm 3.0^{\# *} \dagger$ \\
\hline $\mathrm{DP}(\mathrm{mmHg} / \mathrm{min})$ & $8367.5 \pm 932.7$ & $8418.5 \pm 799.7$ & $8733.4 \pm 1045.0$ & $13018.3 \pm 1449.7^{\# *}$ & $8364.2 \pm 1022.2$ & $20556.5 \pm 2013.8^{\# *} \dagger$ \\
\hline
\end{tabular}

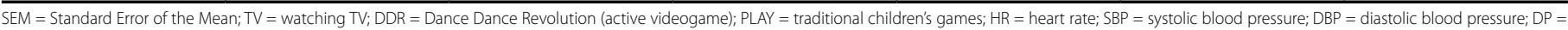
double product. $\# p<0.01$ when compared to rest; ${ }^{*} p<0.01$ when compared to $T V ; t p<0.01$ when compared to DDR. 
Table 4. Mean ( $\pm S D$ ) Values of Kcal Expended at Rest and During Activity and Recovery $(n=16)$.

\begin{tabular}{c|c|c|c}
\hline & TV & DDR & PLAY \\
\hline Rest (kcal/min) & $1.14 \pm 0.17$ & $1.14 \pm 0.17$ & $1.13 \pm 0.16$ \\
\hline Activity (kcal/min) & $1.21 \pm 0.15$ & $1.90 \pm 0,21^{*+}$ & $3.73 \pm 0.65^{* \#+}$ \\
\hline Rec $(\mathrm{kcal} / \mathrm{min})$ & $1.13 \pm 0.21$ & $1.25 \pm 0.17^{*+}$ & $1.53 \pm 0.17^{* \#+}$ \\
\hline Activity (kcal) & $36.39 \pm 4.50$ & $56.98 \pm 6.34^{*}$ & $112.08 \pm 19.45^{* \#}$ \\
\hline Rec (kcal) & $45.48 \pm 8.59$ & $50.18 \pm 7.02^{*}$ & $61.25 \pm 6.78^{* \#}$ \\
\hline Whole session (kcal) & $81.87 \pm 13.1$ & $107.16 \pm 13.36^{*}$ & $173.33 \pm 26.23^{* \#}$ \\
\hline
\end{tabular}

SD = Standard Deviation; Rec = Recovery time; TV = watching TV; DDR = Dance Dance Revolution (active videogame); PLAY = traditional children's games; ${ }^{*} \mathrm{p}<0.01$ when compared to $\mathrm{TV} ; \# \mathrm{p}<0.01$ when compared to $\mathrm{DDR} ; \mathrm{tp}<0.01$ when compared to rest.

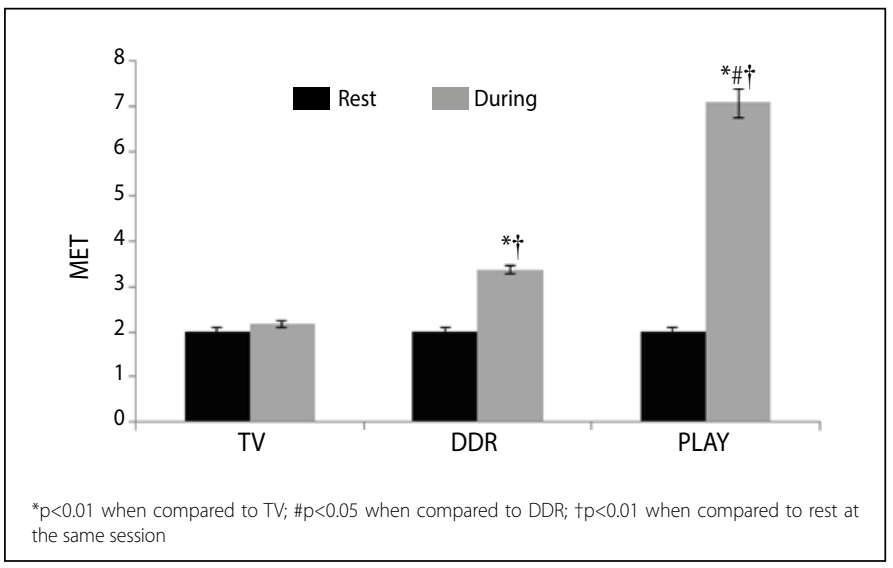

Figure 2. Metabolic Equivalent (MET) During Sessions ( $n=16)$

\section{DISCUSSION}

$\mathrm{VO}_{2}$ and EE were analyzed in children during and after performing both traditional games (PLAY), active videogames (DDR), and watching television (TV). The main findings were that PLAY elicited the highest $\mathrm{VO}_{2}$ and EE during and after exercise (EPOC), although no differences were observed at rest. Even though DDR also showed a significant increase in $\mathrm{VO}_{2}$ and $\mathrm{EE}$ during and after activity when compared to TV, traditional games proved to be superior in increasing $\mathrm{VO}_{2}$, EPOC, and EE.

EPOC occurred during the first 20 minutes of recovery from DDR and during 30 minutes of recovery from PLAY. EPOC occurs when $\mathrm{VO}_{2}$ after exercise is significantly higher than at rest. Elevated $\mathrm{VO}_{2}$ after exercise occurs because of the need for a higher metabolic rate to enable recovery from exercise. The higher metabolic rate is needed due to several reactions related to post-exercise recovery, including the replenishment of oxygen stores, ATP and phosphocreatine resynthesis, lactate clearance, and inflammatory processes associated with exercise-induced muscle damage. ${ }^{11,21}$

In the present study, $\mathrm{VO}_{2}$ elicited by PLAY was $134 \%$ higher than at rest, while in $\mathrm{DDR} \mathrm{VO}_{2}$ was $109 \%$ higher. When comparing $\mathrm{VO}_{2}$ during the post-exercise recovery period, EPOC after PLAY and DDR was 35\% and $10 \%$ higher than after TV, respectively. $\mathrm{VO}_{2}$ during recovery after PLAY was 22\% higher than after DDR. This represents about 16 and $5 \mathrm{kcal}$ more for PLAY and DDR when compared to $T V$, respectively. Although this might seem like a very small difference in EE for a single day. Considering the cumulative effect of this EPOC level over many days, this could positively impact the struggle against obesity. Even such a little extra EE above rest (5-16 kcal/day) may represent 150-480 kcal per month, and 1,800-5,760 $\mathrm{kcal} /$ year. If not expended, this energy would result in 200-640 $\mathrm{g}$ of fat every year. Moreover, if the total amount of EE was considered (entire session plus post-exercise recovery), PLAY resulted in $~ 91$ extra kcal expended when compared to TV. This extra EE represents about 33,000 kcal during an entire year. This would result in about $3.6 \mathrm{~kg}$ of fat, portending a greater risk of obesity and other co-morbid conditions.

Lanningham-Foster et al. ${ }^{22}$ analyzed the EE of 25 children in distinct activities: watching TV while seated, playing traditional/sedentary videogames, watching TV while walking on a treadmill, and playing the Wii Sports Boxing game. EE increased 148\% during the treadmill session and $172 \%$ during the active videogame session when compared to their respective resting values. In the present study, PLAY and DDR resulted in an EE 330\% and 166\% higher than their respective resting values. This demonstrates that traditional games are better than video games or treadmill exercise for eliciting a higher EE. And, although active videogames may be a good alternative, traditional games are better and easily introduced into children's routines at school and home.

Mellecker and McManus ${ }^{23}$ found a higher EE during active videogames when compared to a seated game (XaviX J-Mat Jackie's Action Run vs. XaviX bowling - 10-pin bowling; $5.23 \pm 1.63$ vs $1.31 \pm 0.33$ $\mathrm{kcal} / \mathrm{min}$, respectively). In the present study, PLAY and DDR resulted in $3.73 \pm 0.65$ and $1.90 \pm 0.21 \mathrm{kcal} / \mathrm{min}$ expenditure, respectively. The lower EE in our study may be due to the motor pattern required for each specific game. Moreover, the EE in PLAY was higher probably because running was pivotal, requiring greater involvement of muscle groups than DDR. Although DDR induced less EE than PLAY, it is an effective alternative, as it is cheaper than other active videogames. Furthermore, some children consider this type of game important to encourage more exercise. ${ }^{8}$

EE during active play and EPOC are important for controlling body weight and may be influenced by several factors, including exercise duration and intensity. ${ }^{24}$ In the present study, PLAY performed at higher intensity elicited a higher metabolic rate during exercise and afterwards, in EPOC. These findings were similar to those by Thornton and Potteiger $_{1}^{25}$ who found that more intense resistance exercise elicited a higher EPOC in adults.

For each of the sessions, the EE was 82, 107, and $173 \mathrm{kcal}$ during TV, DDR, and PLAY, respectively. The World Health Organization ${ }^{26}$ recommends at least 60 minutes of daily physical activity for children to be healthy, which is approximately 12,000 steps per day according to Colley et al. ${ }^{27}$ Thus, according to these criteria ( $150 \mathrm{kcal} /$ day), kids would need to participate in PLAY for 30-40 minutes or 80 minutes in DDR to meet the daily recommendations.

RER can provide information about substrate utilization. RER during $P L A Y$ remained close to 1.0 and was significantly higher than DDR and $T V$. During the post-exercise recovery period, RER remained higher until after 20 minutes of PLAY and after 10 minutes of DDR. After those periods, RER decreased until 40 minutes of recovery for PLAY and DDR at which time data collection ceased.

The high value of RER during PLAY suggests a higher glycolytic activity when compared to rest and TV. During intense exercise, RER is close to 1.0, representing the predominant metabolism of carbohydrates. On the other hand, high intensity exercise can cause a lower post-exercise RER, reaching values close to 0.7 , which means a higher rate of fat oxidation. ${ }^{28}$ The body's ability to use fat as an energy source and improve energy balance and weight control is important for preventing obesity ${ }^{29}$. Therefore, high-intensity exercise should be considered as an effective strategy. ${ }^{30}$

Limitations of present study include the small sample size that prevented performing comparisons between genders. However, the kinetics of $\mathrm{VO}_{2}$ is different between boys and girls. Also, EPOC and RER were analyzed only for 40 minutes, thus, it is not possible to determine the responses beyond this time point. 


\section{CONCLUSION}

Traditional children's games that are easy to perform and less expensive showed higher cardiovascular responses, $\mathrm{VO}_{2}$, EPOC, and $\mathrm{EE}$, when compared to active videogame and watching TV. Thus, traditional active games can be a joyful, effective, easily applied, and less expensive way of intervening in the prevention of obesity and associated diseases. Additionally, the benefits active playing goes beyond elevated EE to prevent obesity, since it improves cognitive, psychological, affective, and social health. Moreover, an active videogame like DDR is a safe, fun, and valuable way to increase EE in children who spend considerable time in front of the TV and others sedentary activities.

\section{ACKNOWLEDGEMENTS}

The authors would like to thank the CNPq for the scholarships and the colleagues of Suliane Beatriz Rauber for assisting with data collection.

All authors declare no potential conflict of interest related to this article.

AUTHORS' CONTRIBUTIONS: Each author contributed individually and significantly to the development of the manuscript. SBR (0000-0003-3091-8464) * JFVNM (0000-00027394-7700) * PSB (0000-0003-4176-1159) * CSGC (0000-0001-5946-7180) * were the main contributors in writing the manuscript. SBR, CSGC, DFB (0000-0002-8251-0105) *, BM (0000-0003-1355-5788) *, HGS (0000-0002-2378-4026) * and JEL (0000-0002-8490-7368) * contributed substantially to design, data collection, analysis and interpretation . SBR, CSGC, JFVNM and BM and DFB: bibliographic research, manuscript's revision and submission. *ORCID (Open Researcher and Contributor ID).

\section{REFERENCES}

1. Kohl HW 3rd, Craig CL, Lambert EV, Inoue S, Alkandari JR, Leetongin G, et al. The pandemic of physical inactivity: global action for public health. Lancet. 2012;380(9838):294-305.

2. Centers for Disease Control and Prevention (CDC). School health guidelines to promote healthy eating and physical activity. MMWR Recomm Rep. 2011;60(RR-5):1-76.

3. Flechtner-Mors M, Neuhauser $H$, Reinehr T, Roost HP, Wiegand S, Siefried W, et al. Blood pressure in 57,915 pediatric patients who are overweight or obese based on five reference systems. Am J Cardiol. 2015;115(11):1587-94

4. Carson V, Kuzik N, Hunter S, Wiebe SA, Spencer JC, Friedman A, et al. Systematic review of sedentary behavior and cognitive development in early childhood. Prev Med. 2015;78:115-22.

5. LeBlanc AG, Chaput JP, MCFarlane A, Colley RC, Thivel D, Biddle SJH, et al. Active video games and health indicators in children and youth: a systematic review. PLoS One. 2013;8(6):e65351.

6. White K, Schofield G, Kilding AE. Energy expended by boys playing active video games. J Sci Med Sport. 2011;14(2):130-4.

7. Rauber SB, Boullosa DA, Carvalho FO, Moraes JF, Sousa IR, Simões HG, et al. Traditional games resulted in post-exercise hypotension and a lower cardiovascular response to the cold pressor test in healthy children. Front Physiol. 2014;5:235.

8. Simons M, Brug J, Chinapaw MJ, de Boer M, Seidell J, de Vet E. Replacing Non-Active Video Gaming by Active Video Gaming to Prevent Excessive Weight Gain in Adolescents. PLoS One. 2015;10(7):e0126023.

9. Simons M, Chinapaw MJ, van de Bovenkamp M, Boer MR, Seidell JC, Brug J, et al. Active video games as a tool to prevent excessive weight gain in adolescents: rationale, design and methods of a randomized controlled trial. BMC Public Health. 2014;14:275.

10. Armstrong N, Barker AR. Oxygen uptake kinetics in children and adolescents: a review. Pediatr Exerc Sci. 2009;21(2):130-47.

11. Egan B, Zierath JR. Exercise metabolism and the molecular regulation of skeletal muscle adaptation Cell Metab. 2013;17(2):162-84

12. Christiansen E, Garby L, Sorensen TI. Quantitative analysis of the energy requirements for development of obesity. J Theor Biol. 2005;234(1):99-106.

13. Zanni E, Magosso RF, Silva NS, Robert-Pires CM. Consumo excessivo de oxigênio após exercício (EPOC) em mulheres idosas submetidas a uma sessão de exercício resistido. Revista Brasileira de Prescrição e Fisiologia do Exercício. 2013;7(38):190-6.

14. Maehlum S, Grandmontagne M, Newsholme EA, Sejersted OM. Magnitude and duration of excess postexercise oxygen consumption in healthy young subjects. Metabolism. 1986;35(5):425-9.

15. Goran MI. Energy metabolism and obesity. Med Clin North Am. 2000;84(2):347-62.
16. Bahr R, Ingnes I, Vaage O, Sejersted OM, Newsholme EA. Effect of duration of exercise on excess postexercise O2 consumption. J Appl Physiol (1985). 1987;62(2):485-90.

17. Cunha FA, Midgley AW, McNaughton LR, Farinatti PT. Effect of continuous and intermittent bouts of isocaloric cycling and running exercise on excess postexercise oxygen consumption. J Sci Med Sport 2016:19(2):187-92.

18. Slaughter MH, Lohman TG, Boileau RA, Horswill CA, Stillman RJ, et al. Skinfold equations for estimation of body fatness in children and youth. Hum Biol. 1988;60(5):709-23.

19. Onis M. WHO Child Growth Standards based on length/height, weight and age. Acta Paediatr Suppl. 2006:450:76-85.

20. National High Blood Pressure Education Program Working Group on High Blood Pressure in Children and Adolescents. The fourth report on the diagnosis, evaluation, and treatment of high blood pressure in children and adolescents. Pediatrics. 2004;114(2 Suppl 4th Report):555-76.

21. Borsheim E, Bahr R. Effect of exercise intensity, duration and mode on post-exercise oxygen consumption Sports Med. 2003;33(14):1037-60.

22. Lanningham-Foster L, Jensen TB, Foster RC, Redmond AB, Walker BA, Heinz D, et al. Energy expenditure of sedentary screen time compared with active screen time for children. Pediatrics. 2006;118(6):e1831-5.

23. Mellecker RR, McManus AM. Energy expenditure and cardiovascular responses to seated and active gaming in children. Arch Pediatr Adolesc Med. 2008;162(9):886-91.

24. Da Silva RL, Brentano MA, Kruel LF. Effects of different strength training methods on postexercise energetic expenditure. J Strength Cond Res. 2010;24(8):2255-60.

25. Thornton MK, Potteiger JA. Effects of resistance exercise bouts of different intensities but equal work on EPOC. Med Sci Sports Exerc. 2002;34(4):715-22

26. WHO. Global recommendations on physical activity for health. In: Organization WH, 2010.

27. Colley RC, Janssen I, Tremblay MS. Daily step target to measure adherence to physical activity guidelines in children. Med Sci Sports Exerc. 2012;44(5):977-82

28. Brown BE, Mahroof FM, Cook NL, van Reyk DM, Davies MJ. Hydrazine compounds inhibit glycation of low-density lipoproteins and prevent the in vitro formation of model foam cells from glycolaldehyde-modified low-density lipoproteins. Diabetologia. 2006;49(4):775-83.

29. Blair SN, Hand GA, Hill JO. Energy balance: a crucial issue for exercise and sports medicine. Br J Sports Med. 2015;49(15):970-1.

30. Perry CG, Heigenhauser GJ, Bonen A, Spriet LL. High-intensity aerobic interval training increases fat and carbohydrate metabolic capacities in human skeletal muscle. Appl Physiol Nutr Metab. 2008:33(6):1112-23. 